\title{
Endoscopic Resection
}

National Cancer Institute

\section{Source}

National Cancer Institute. Endoscopic Resection. NCI Thesaurus. Code C159453.

Surgical resection using endoscopy. 